$9-1-2000$

\title{
Underwriter Reputation and Short-Run IPO Returns: A Re- evaluation for an Emerging Market
}

Nuray Guner

Middle East Technical University

Zeynep Onder

Bilkent University

Seza Danisoglu Rhoades

Middle East Technical University

Follow this and additional works at: https://ecommons.luc.edu/meea

Part of the Economics Commons

\section{Recommended Citation}

Guner, Nuray; Onder, Zeynep; and Rhoades, Seza Danisoglu, "Underwriter Reputation and Short-Run IPO Returns: A Re-evaluation for an Emerging Market ". Topics in Middle Eastern and North African Economies, electronic journal, 2, Middle East Economic Association and Loyola University Chicago, 2000, http://www.luc.edu/orgs/meea/

This Article is brought to you for free and open access by the Journals and Magazines at Loyola eCommons. It has been accepted for inclusion in Topics in Middle Eastern and North African Economies by an authorized administrator of Loyola eCommons. For more information, please contact ecommons@luc.edu. (C) 2000 the authors 


\title{
UNDERWRITER REPUTATION AND SHORT-RUN IPO RETURNS:
}

\author{
A RE-EVALUATION FOR AN EMERGING MARKET
}

Nuray Guner, Department of Business Administration, Middle East Technical University, E-mail: nguner@ba.metu.edu.tr

Zeynep Onder, Department of Management, Bilkent University, E-mail: zonder@bilkent.edu.tr Seza Danisoglu Rhoades, Department of Business Administration, Middle East Technical University, Email: seza@ba.metu.edu.tr

\begin{abstract}
This study examines the effect of underwriter reputation on the initial-day IPO returns in an emerging market. It uses both a traditional and an extended model given the characteristics of the IPO market under analysis. The results from the traditional model indicate that underwriter reputation does not affect the initial day IPO returns. However, after controlling for factors that are important in determining the price of an IPO in an emerging market, a complex relationship between underwriter reputation measures and IPO returns is documented. Results in this paper indicate that it is not appropriate to extend the findings in the US to other markets without taking into account the unique characteristics of these markets.
\end{abstract}

The short- and long-run performances of Initial Public Offerings (IPOs) have long been an issue of interest in the finance literature. Previous studies have shown that the IPOs of common stock yield positive short-run raw returns and negative long-run market-adjusted returns (Rock, 1986; Jog and Riding, 1987; Tinic, 1988, Finn and Higham, 1988; Ritter, 1991; Keasey and Short, 1992; Levis, 1993; Kunz and Aggarwal, 1994; Lee, Taylor and Walter, 1996a). The positive short-run returns documented in the literature are interpreted as an evidence of underpricing in the offer price. Carter and Manaster (1990) develop an equilibrium model that explains the relationship between this underpricing and the prestige of the underwriter who brings the issue to the market. According to their model, prestigious underwriters (those with high reputation) are associated with lower amounts of IPO underpricing. Since the early 1970s, several studies have tested this argument by using different measures of underwriter reputation (McDonald and Fisher, 1972; Block and Stanley, 1980; Neuberger and LaChapelle, 1983; Beatty and Ritter, 1986; Johnson and Miller, 1988; Carter and Manaster, 1990; Booth and Chua, 1996; Nanda and Yun, 1997; Carter, Dark and Singh, 1998). All these studies conclude that, on average, short-run returns are less positive for those IPOs that are brought to the market by more prestigious underwriters. In this study, the objective is to examine the relationship between underwriter reputation and IPO performance in an emerging market. Similar to results from developed markets, several studies document positive abnormal initial day IPO returns in emerging markets (Dawson, 1987; Aggarwal, Leal and Hernandez, 1993; Lee, Taylor and Walter, 1996b). On the other hand, several characteristics of emerging markets might cause the relationship between underwriter reputation and IPO performance in these markets to be different than the relationship observed in developed markets (Harvey, 1995). It is usually argued that the information asymmetry is severe and the informational efficiency is low in emerging markets. As a result, it takes a long time for any information to be fully reflected in asset prices and it is more costly for investors to collect and process information in these markets. Hence, on one hand, underwriter reputation 
can be very helpful for investors in solving their asymmetric information problems in such a market. On the other hand, the information asymmetry might be so severe that, unlike the case in an informationally efficient market, the underwriter reputation may not be sufficient to reduce this asymmetry between the firm going public and investors in an inefficient market. Furthermore, it might be difficult for investors to assess the reputation of the underwriter itself as a result of the severe information asymmetries. Therefore, even though prior research documents the significant negative impact of underwriter reputation on IPO performance in the US market, it may not be plausible to expect such a relationship to exist for IPOs in an emerging market. As a result, it is difficult to determine a priori the impact of underwriter reputation on IPO performance in such a market. This is an issue that needs to be examined empirically.

This paper analyzes the relationship between underwriter reputation and IPO underpricing in the Istanbul Stock Exchange (ISE). Domestic and foreign investors alike who are investing in emerging markets with characteristics similar to the ISE can benefit from the results of this paper. The sample consists of one hundred and eighteen IPOs that took place during a period from January, 1993 to June, 1999. The underwriter reputation is proxied by four measures developed using the number and the dollar magnitude of size the offerings an underwriter conducts. . A traditional model (used in studies for the US) and its modified version for an emerging market are estimated to test the relationship between underwriter reputation and IPO underpricing.

Given the available data on underwriters in Turkey, it is not possible to estimate all of the underwriter reputation measures used in the US. Therefore, modified versions of the Johnson and Miller and the Megginson and Weiss measures are calculated for the underwriters. Also, two new reputation measures are suggested given the characteristics of the IPO market in Turkey. In summary, four different reputation measures are calculated for the underwriters.

When the traditional model is estimated for the IPOs in Turkey (Table I), no relationship between initial day IPO returns and the underwriter reputation is documented regardless of which reputation measure is used. The only variable that explains the initial day IPO returns is the 15-day return on the market index before the first day of trading (institutional lag variable). The relationship between initial day IPO returns and this institutional lag variable is positive. This result implies that if the market increases between the IPO date and the first day of trading, the initial day IPO returns will be positive as well.

The traditional model is extended to account for the unique characteristics of the IPO market in Turkey (Table II). Two reputation measures that account for different aspects of underwriter reputation are included and four more control variables are added to the models. The first reputation measure assumes that two underwriters with the highest number of IPOs lead or co-lead are prestigious and the rest are not. This variable measures the visibility of an underwriter in the IPO market. The second reputation variable in the regression is a proxy for the volume of IPO business (either in dollar amount or in number) lead or co-lead by an underwriter. In this extended model, a negative relationship between the initial day IPO returns and the visibility measure is found. This finding indicates that since these underwriters are well known by the investors, they underprice to a lesser degree. On the other hand, the relationship between the volume of IPOs and the initial day IPO returns is positive. The more IPOs an underwriter handles, the harder it would be to sell the shares. Therefore, these underwriters have to underprice to a higher degree. These results suggest that in contrast to the evidence for the US IPOs, the relationship between initial day IPO returns and underwriter reputation is rather complex in the ISE.

In addition to the institutional lag variable, two more control variables have a statistically significant impact on IPO underpricing. These variables are the age of the firm and a dummy variable for relatedness of the IPO firm and the underwriter. The age has a positive and statistically significant coefficient in these regressions indicating that older firms will be underpriced to a higher degree. This conflicting finding could be a result of the opaque ownership structure in Turkey. The related variable has positive and statistically significant coefficient as well, implying that those IPOs brought to the market by underwriters owned by the same parent company as the issuing firm will be underpriced to a higher degree. This finding indicates that the 
asymmetric information between investors and IPO firms is the main determinant of the level of underpricing in Turkey. When the underwriter is not related to the IPO firm, the investors have a greater confidence in the certification of the IPO price provided by the independent underwriter. As a result, underwriters that are not owned by the same parent company as the issuing firm do not have to underprice as much as the non-related underwriters. On the other hand, when the underwriter and the IPO firm are owned by the same parent company, the price certification provided by this underwriter does not have as much value as that provided by an independent underwriter for the investors. Therefore, in this case, investors require a higher discount to participate in these IPOs.

The findings of this paper indicate that evidence on underwriter reputation and initial day IPO returns documented in the US cannot be extended to emerging markets without any modification. The results here can be extended to other emerging markets with similar characteristics as the ISE. Since the participation of international investors in the IPOs of emerging markets is quite common, the findings of this paper have some investment implications for international investors.

\section{REFERENCES}

Aggarwal, R.; Leal, R. and Hernandez, L. "The After Market Performance of Initial Public Offerings in Latin America." Financial Management, 1993, 22, pp.42-53.

Aydogan, K. and Muradoglu, G. "Do Markets Learn from Experience? Price Reactions to Stock Dividends in the Turkish Market." Applied Financial Economics, 1998, 8, pp. 41-60.

Balaban, E. and Kunter, K. "Financial Market Efficiency in A Developing Country: The Turkish Case." Unpublished manuscript, 1998, Research Department, The Central Bank of the Republic of Turkey.

Beatty, R.and Ritter, J. "Investment Banking, Reputation and Underpricing of Initial Public Offerings." Journal of Financial Economics, 1986, 15, pp. 213-232.

Block, S.and Stanley, M. "The Financial Characteristics and Price Movement Patterns of Companies Approaching the Unseasoned Securities Market in the Late 1970s." Financial Management, 1980, 9(4), pp. 30-36.

Booth, J.R. and Chua, L. "Ownership Dispersion, Costly Information, and IPO Underpricing." Journal of Financial Economics, 1996, 41, pp. 201-310.

Carter, R.B.; Dark, F.H. and Singh, A.K. "Underwriter Reputation, Initial Returns and Long Run Performance of IPO Stocks." The Journal of Finance, March 1998, 53(1), pp. 285-311.

Carter, R.B. and Manaster, S. "Initial Public Offerings and Underwriter Reputation." The Journal of Finance, September 1990, 45 (4), pp. 1045-1068.

Dawson, M. S. "Secondary Stock Market Performance of Initial Public Offers, Hong Kong, Singapore, and Malaysia: 1978-1984." Journal of Business, Finance and Accounting, 1987, 14, pp. 65-76.

Finn, F. J. and Higham, R. "The Performance of Unseasoned New Equity Issues-cum-stock Exchange Listings in Australia." Journal of Banking and Finance, 1988, 12, pp. 333-351.

Grinblatt, M., and Hwang, C. "Signaling and the Pricing of New Issues." The Journal of Finance, June 1989, 44(2), pp. 393-420.

Harvey, C. R. "Predictable Risk and Returns in Emerging Markets." The Review of Financial Studies, Fall 
1995, 8(3), pp. 773-816.

ISE. Firms Going Public, 1998, Istanbul: Emir Ofset Matbaa Ltd. Sti.

Jog, V.M., and Riding, A.L. "Underpricing in Canadian IPOs." Financial Analysts Journal, 1987, 43, pp. 4854.

Johnson, J. and Miller, R. "Investment Banker Prestige and the Underpricing of Initial Public Offerings." Financial Management, 1988, 17(2), pp. 19-29.

Keasey, K. and Short, H. "The Underpricing of Initial Public Offerings, pp. Some UK Evidence." International Journal of Management Science, 1992, 20, pp. 457-466.

Kunz, R.M., and Aggarwal, R. "Why Initial Public Offerings Are Underpriced: Evidence from Switzerland." Journal of Banking and Finance, 1994, 18, pp. 705-723.

Lee, P.J.; S.L. Taylor, and T.S. Walter. "Australian IPO Pricing in the Short- and Long-Run." Journal of Banking and Finance, 1996a, 20, pp. 1189-1210.

. "Expected and Realized Returns for Singaporean IPOs, pp. Initial and Long-Run Analysis." Pacific-Basin Journal, 1996b, 4, pp. 153-180

Leland, H.E., and Pyle, D.H. "Informational Asymmetries, Financial Structure, and Financial Intermediation." The Journal of Finance. May 1977, 32(2), pp. 371-387.

Levis, M. "The Long-run Performance of Initial Public Offerings: The U.K. Experience 1980-1988." Financial Management, 1993, 22, pp. 28-41.

Logue, D.E. "On the Pricing of Unseasoned Equity Issues, 1965-1969." Journal of Financial and Quantitative Analysis, January 1973, 8(1), pp. 91-103.

McDonald, J.G. and Fisher, A. K. "New-Issue Stock Price Behavior." The Journal of Finance, March 1972, 27(1), pp. 97-102.

Megginson, W. and Weiss, K. "Venture Capitalist Certification in Initial Public Offerings." The Journal of Finance, July 1991, 46(3), pp. 879-904.

Michaely, R. and Shaw, W. "The Pricing of Initial Public Offerings, pp. Tests of Adverse Selection and Signaling Theories." The Review of Financial Studies, Summer 1994, 7(2), pp. 279-319.

Muradoglu, G. and Unal, M. "Weak-form Efficiency in the Thinly Traded Istanbul Securities Exchange." Middle East Business and Economic Review, 1994, 6, pp. 37-44.

Nanda, V., and Yun, Y. 1997. "Reputation and Financial Intermediation, pp. An Empirical Investigation of the Impact of IPO Mispricing on Underwriter Market Value." Journal of Financial Intermediation, 1997, 6, pp. 39-63.

Neuberger, B.M. and LaChapelle, C.A. "Unseasoned New Issue Price Performance on Three Tiers, pp. 19751980." Financial Management, 1983, 12(3), pp. 23-28.

Onder, Z. Causes and Consequences of Ownership Structure, pp. Evidence from Performance of Turkish Firms. 1999, Bilkent University working paper. 
Ritter, J. "The Cost of Going Public." Journal of Financial Economics, 1987, 19, pp. 269-281.

Ritter, J. "The Long-Run Performance of Initial Public Offerings." The Journal of Finance, March 1991, 46(1), pp. 3-27.

Rock, K. "Why New Issues Are Underpriced." Journal of Financial Economics, 1986, 15, pp. 187-212.

Sermaye Piyasasi ve Borsa Temel Bilgiler Kilavuzu. 1997. IMKB Egitim Yayinlari No, pp.1 Denge Ofset Matbaacilik. Istanbul.

Tinic, S. "Anatomy of Initial Public Offerings of Common Stock." The Journal of Finance, September 1988, 43(4), pp. 789-822.

Yurtoglu, B.B. 1998, "Ownership Structure of Turkish Listed Firms." University of Vienna working paper.

\section{Table I}

\section{Regression - Traditional Model}

This table reports the regression estimates of initial IPO returns on four different reputation measures and five control variables. The regression model is a linear specification of the following equation:

$I P O$ return $=\mathrm{f}($ Reputation, Age of Issuing firm, Insider shares, Offer size, Risk, Market Performance)

IPO return is the simple one-day return calculated from the offer price and the closing price on the first trading day of the IPO shares Reputation is one of the four reputation measures used in the study. REP1 is the Megginson and Weiss (MW) measure where reputation is measured as the ratio of the total dollar amount of IPOs brought to the market by the lead underwriter of a given IPO to the total dollar amount of all IPOs in the sample. REP2 is calculated by taking the ratio of the number of IPOs underwritten by an underwriter to the total number of IPOs during the sample period. REP3 is a 4-scale measure and it classifies underwriters into four groups based on their REP1 measure. REP4 is a 2-level scale measure. It takes a value of 1 if the underwriter is one of the first two underwriters with the highest REP2 score in the sample and a value of 0 for the rest. Age of the issuing firm is the number of years the issuing firm has been in operation between its inception and June 30, 1999. Insider shares is the percentage of the IPO issue that is offered from the holdings of the shareholders. Risk is the standard deviation of IPO returns over a 20-day period starting from the second day of trading. Offer size is the size of the IPO issue in millions of dollars. Market performance is the 15-day return on the market index prior to the first trading day of the IPO shares. 


\begin{tabular}{lcccc}
\hline & Coefficient & Coefficient & Coefficient & Coefficient \\
\hline Intercept & 23.4531 & 21.3684 & 22.8861 & 21.5177 \\
& $(1.282)$ & $(1.179)$ & $(1.266)$ & $(1.195)$ \\
Reputation Variables & & & & \\
REP1 & 0.1782 & & & \\
REP2 & $(0.713)$ & & & \\
REP3 & & -0.0671 & & \\
& & $(-0.282)$ & & \\
REP4 & & & 1.0627 & \\
Control Variables & & & $(1.037)$ & -3.0772 \\
Age of 1ssuing Firm & 1.0574 & 1.1307 & 1.0349 & 1.2011 \\
& $(1.219)$ & $(1.294)$ & $(1.196)$ & $(1.388)$ \\
Insider Shares & -0.3414 & -0.5042 & -0.5639 & -0.6669 \\
& $(-0.143)$ & $(-0.211)$ & $(-0.238)$ & $(-0.281)$ \\
Offer Size & -1.1585 & -0.9517 & -1.2267 & -0.9499 \\
& $(-1.071)$ & $(-0.896)$ & $(-1.139)$ & $(-0.905)$ \\
Risk & -0.0583 & -0.0349 & -0.0588 & -0.0364 \\
Market Performance & $(-0.226)$ & $(-0.136)$ & $(-0.229)$ & $(-0.142)$ \\
& $0.2500^{* * *}$ & $0.2585^{* * *}$ & $0.2483^{* * *}$ & $0.2582^{* * *}$ \\
& $(2.918)$ & $(3.016)$ & $(2.909)$ & $(3.044)$ \\
Adj. R ${ }^{2}$ & & & & \\
F-statistic & & & & \\
$\mathrm{N}$ & 0.0446 & 0.0409 & 0.0494 & 0.0527 \\
\hline
\end{tabular}

\section{Table II}

\section{Regression - Extended Model}

This table reports the regression estimates of initial IPO returns on four different reputation measures and five control variables. The regression model is a linear specification of the following equation:

$I P O$ return $=\mathrm{f}$ (Reputation, Age of Issuing firm, Insider shares, Offer size, Risk, Market Performance, Bank, Related, Sales method, Requirement)

IPO return is the simple one-day return calculated from the offer price and the closing price on the first trading day of the IPO shares Reputation is one of the four reputation measures used in the study. REP1 is the Megginson and Weiss (MW) measure where reputation is measured as the ratio of the total dollar amount of IPOs brought to the market by the lead underwriter of a given IPO to the total dollar amount of all IPOs in the sample. REP2 is calculated by taking the ratio of the number of IPOs underwritten by an underwriter to the total number of IPOs during the sample period. REP3 is a 4-scale measure and it classifies underwriters into four groups based on their REP1 measure. REP4 is a 2-level scale measure. It takes a value of 1 if the underwriter is one of the first two underwriters with the highest REP 2 score in the sample and a value of 0 for the rest. Age of the issuing firm is the number of years the issuing firm has been in operation between its inception and June 30, 1999. Insider shares is the percentage of the IPO issue that is offered from the holdings of the shareholders. Risk is the standard deviation of IPO returns over a 20-day period starting from the second day of trading. Offer size is the size of the IPO issue in millions of dollars. Market performance is the 15-day return on the market index prior to the first trading day of the IPO shares. Bank is a dummy variable that takes a value of 1 for banks or bank-affiliated underwriters. Related is a dummy variable that takes a value of 1 if the issuing firm and the underwriter are owned by the same individuals or by the same parent company. Sales method, is a dummy variable that takes a value of one if the sales method in underwriting is a fixed price offer and zero if the shares are either sold directly on the Istanbul Stock Exchange or the book-building method is used. Requirement is a dummy variable that takes a value of 1 if the issuing firm and the underwriter are owned by the same individuals or by the same parent company. 


\begin{tabular}{lcccc}
\hline & Coefficient & Coefficient & Coefficient & Coefficient \\
\hline Intercept & 23.4531 & 21.3684 & 22.8861 & 21.5177 \\
& $(1.282)$ & $(1.179)$ & $(1.266)$ & $(1.195)$ \\
Reputation Variables & & & & \\
REP1 & 0.1782 & & & \\
REP2 & $(0.713)$ & & & \\
REP3 & & -0.0671 & & \\
REP4 & & $(-0.282)$ & & \\
& & & 1.0627 & \\
Control Variables & & & $(1.037)$ & -3.0772 \\
Age of 1ssuing Firm & 1.0574 & 1.1307 & 1.0349 & 1.2011 \\
Insider Shares & $(1.219)$ & $(1.294)$ & $(1.196)$ & $(1.388)$ \\
& -0.3414 & -0.5042 & -0.5639 & -0.6669 \\
Offer Size & $(-0.143)$ & $(-0.211)$ & $(-0.238)$ & $(-0.281)$ \\
Risk & -1.1585 & -0.9517 & -1.2267 & -0.9499 \\
& $(-1.071)$ & $(-0.896)$ & $(-1.139)$ & $(-0.905)$ \\
Market Performance & -0.0583 & -0.0349 & -0.0588 & -0.0364 \\
& $(-0.226)$ & $(-0.136)$ & $(-0.229)$ & $(-0.142)$ \\
Adj. R ${ }^{2}$ & $0.2500 * * *$ & $0.2585 * * *$ & $0.2483^{* * *}$ & $0.2582^{* * *}$ \\
F-statistic & $(2.918)$ & $(3.016)$ & $(2.909)$ & $(3.044)$ \\
N & & & & \\
\hline & 0.0446 & 0.0409 & 0.0494 & 0.0527 \\
& 1.909 & 1.831 & 2.013 & 2.0850 \\
& 117 & 117 & 117 & 117 \\
\hline & & & &
\end{tabular}

